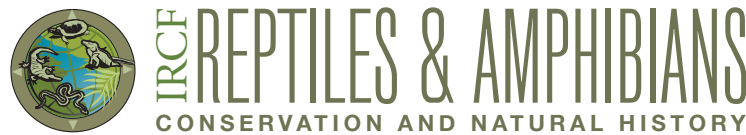

\section{First Record of the Jampui Bent-toed Gecko, Cyrtodactylus montanus Agarwal, Mahony, Giri, Chaitanya, and Bauer 2018 (Squamata: Geklonidae), from Mizoram, India}

\author{
Lal Muansanga ${ }^{1}$, Ht Decemson ${ }^{1}$, Lal Biakzuala ${ }^{1}$, Gospel Zothanmawia $\operatorname{Hmar}^{1}$, H.T. Lalremsanga ${ }^{1}$, Madhurima Das ${ }^{2,3}$, \\ and Jayaditya Purkayastha ${ }^{3}$ \\ ${ }^{1}$ Department of Zoology, Mizoram University, Aizawl 796004, Mizoram, India \\ ${ }^{2}$ IBT Hub, Arya Vidyapeeth College, Guwahati 781016, Assam, India \\ ${ }^{3}$ Help Earth, Raghunath Choudhury Path, Lachitnagar, Guwahati 781007, Assam, India (mail.jayaditya@gmail.com)
}

Cyrtodactylus Gray is the world's most speciose gekko-
nid genus and is currently represented by 291 species (Uetz et al. 2020). The Indo-Burmese Region is represented by about 27 species, of which nine are known from northeastern Indian states: C. guwahatiensis (Assam), C. jaintiaensis (Meghalaya), C. kazirangaensis (Assam), C. khasiensis (presumed to be distributed throughout northeastern India), C. montanus (Tripura), C. nagalandensis (Nagaland), C. septentrionalis (Assam), C. tripuraensis (Tripura), and C. urbanus (Assam) (Purkayastha et al. 2020 ). Of those nine spe-

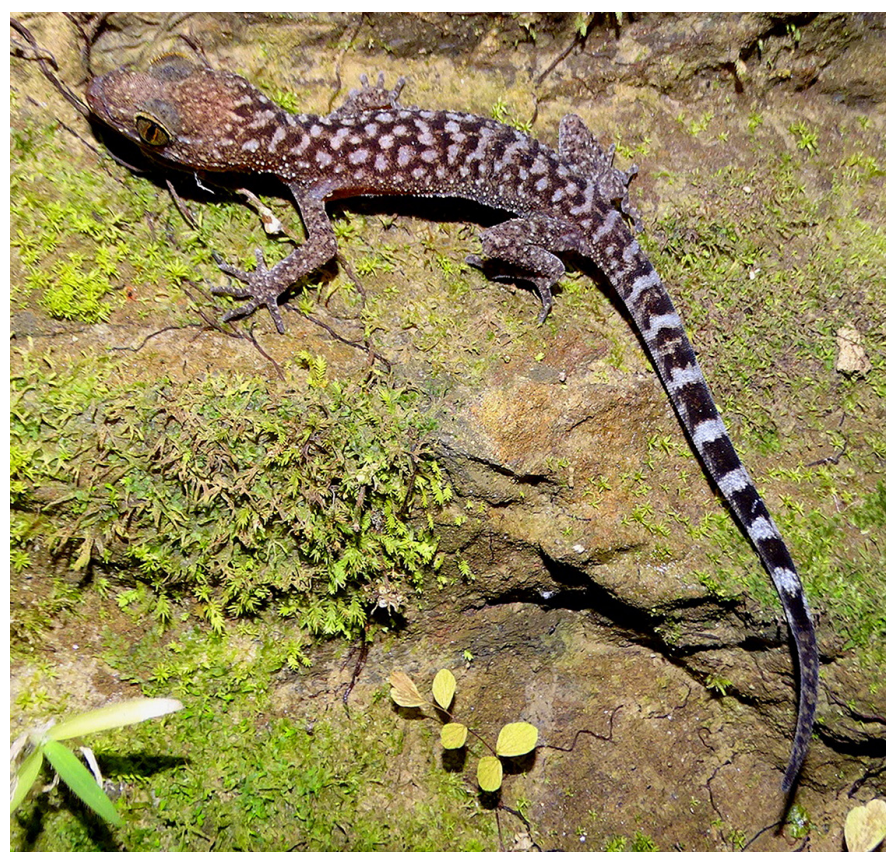

Fig. 1. A female Jampui Bent-toed Gecko (Cyrtodactylus montanus) from Pathlawi Lunglen Tlang, Dampa Tiger Reserve, Mizoram, India. Photograph by H.T. Lalremsanga. cies, eight have been described since 2018. Previously, the only species of Cyrtodactylus recognized from northeastern

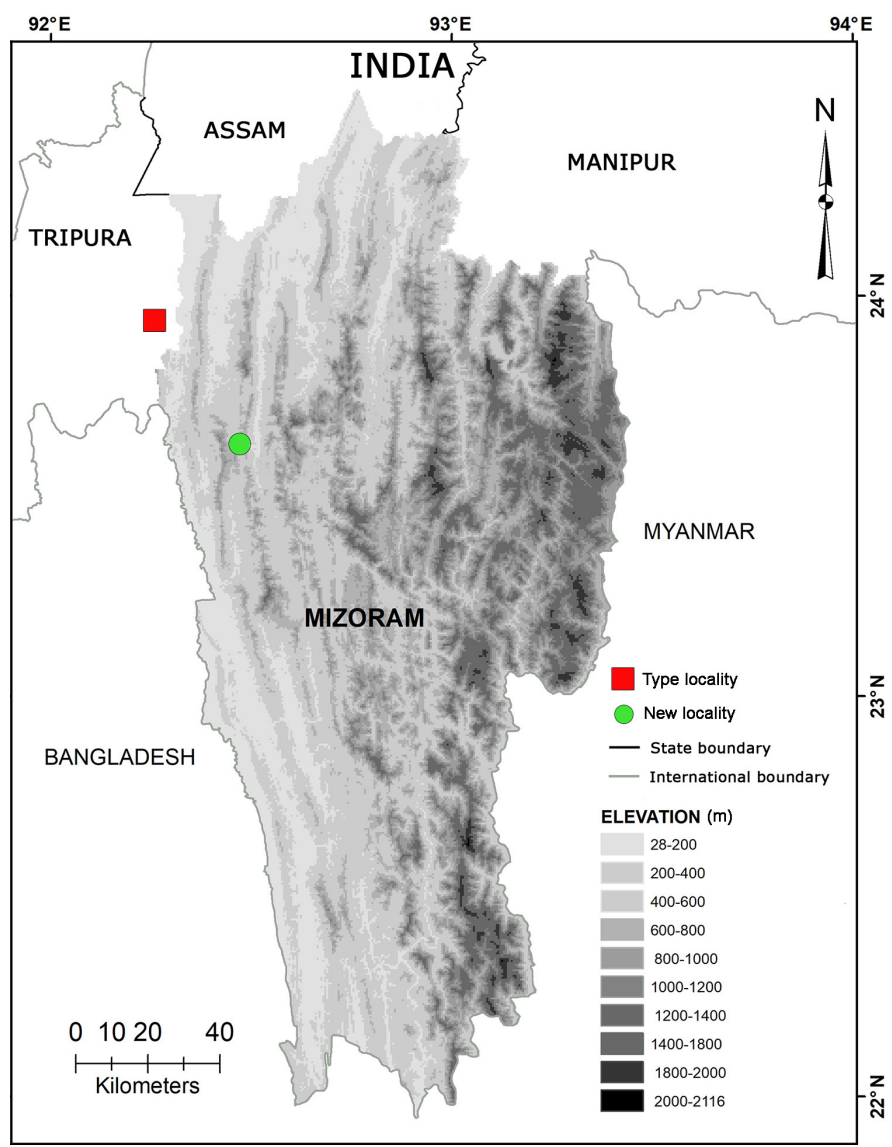

Fig. 2. Map showing the type locality of the Jampui Bent-toed Gecko (Cyrtodactylus montanus) in the Jampui Hills, Tripura, India (red square) and the new locality record at Pathlawi Lunglen Tlang, Dampa Tiger Reserve, Mizoram, India (green dot). 
Table 1. Uncorrected p-distances between species of Bent-toed Geckos (Cyrtodactylus) known to occur in northeastern India (851 nucleotides, ND2). GenBank accession numbers are listed in parentheses after the name of the species.

Cyrtodactylus montanus (MT250544)

\begin{tabular}{|c|c|c|c|c|c|c|c|c|c|c|}
\hline Cyrtodactylus montanus (KM255200) & 0.00 & & & & & & & & & \\
\hline Cyrtodactylus tripuraensis (KM255202) & 0.23 & 0.23 & & & & & & & & \\
\hline Cyrtodactylus guwahatiensis (KM255194) & 0.18 & 0.18 & 0.11 & & & & & & & \\
\hline Cyrtodactylus urbanus (MN911174) & 0.24 & 0.24 & 0.12 & 0.14 & 0.12 & & & & & \\
\hline Cyrtodactylus khasiensis (KM255188) & 0.22 & 0.22 & 0.21 & 0.19 & 0.18 & 0.17 & & & & \\
\hline Cyrtodactylus sp. Mizoram (KM255197) & 0.09 & 0.09 & 0.23 & 0.21 & 0.23 & 0.23 & 0.21 & 0.25 & & \\
\hline Cyrtodactylus jaintiaensis (KM255195) & 0.18 & 0.18 & 0.25 & 0.23 & 0.23 & 0.23 & 0.27 & 0.29 & 0.20 & \\
\hline Cyrtodactylus nagalandensis (KM255199) & 0.19 & 0.19 & 0.266 & 0.23 & 0.25 & 0.22 & 0.21 & 0.25 & 0.16 & 0.18 \\
\hline
\end{tabular}

India was $C$. khasiensis, and until now that is the only species recorded from the state of Mizoram. Herein we report the first record of the Jampui Bent-toed Gecko (C. montanus) from Mizoram, which also is the first record of the species other than from its type locality in the Jampui Hills, Tripura $\left(23.8225^{\circ} \mathrm{N}, 92.2603^{\circ} \mathrm{E}\right.$; elev. $850 \mathrm{~m}$ asl), $20.1 \mathrm{~km}$ airline distance northwest of the new locality.

On 13 February 2020, during a survey in the Dampa Tiger Reserve, we collected a female Cyrtodactylus (Fig. 1) from alongside a trail up a hill called Pathlawi Lunglen Tlang $\left(23.7051^{\circ} \mathrm{N}, 92.4075^{\circ} \mathrm{E}\right.$; elev. $553 \mathrm{~m}$ asl) (Fig. 2). We preserved the gecko in $70 \%$ ethanol, extracted the liver for genetic analysis, and accessioned the specimen in the Departmental Museum of Zoology, Mizoram University (MZMU 1630). Snout-to-vent length was $54.4 \mathrm{~mm}$ and meristics were 10/10 supralabials, 9/9 infralabials, 39 longitudinal rows of rounded dorsal tubercles, 23 paravertebral tubercles, 23 ventral scales between ventrolateral folds, and 16 subdigital lamellae beneath toe IV of the pes. Dorsal coloration consisted of thick dark reticulations enclosing lighter blotches; the tail had alternating dark and lighter bands.

We generated partial ND2 sequences and used the primers MetF1 and H5934 (Macey et al. 1997) for amplification in order to compare all of the species currently known to occur in northeastern India. Using Mega 7 (Kumar et al. 2016), we calculated uncorrected p-distances (Table 1). The results showed zero pair-wise distance between the gecko from Mizoram (GenBank No. MT250544) and a female of the type series of C. montanus (GenBank No. KM255200).

\section{Acknowledgements}

This work was conducted with financial support from the National Mission on Himalayan Studies (NMHS) and implemented by the Ministry of Environment, Forest and Climate Change (MoEF\&CC), New Delhi. We are very grateful to the Field Director, Beat Officer, and Field guide, Dampa Tiger Reserve (DTR), and to Remruatpuii, Saisangpuia, Vanlalsiammawii, and V. L. Malsawmhriatzuali, Department of Zoology, Mizoram University, for their assistance in the field. The permit to conduct this study (No: A. 33011/2/2012CWLW of 13/12/2019) was issued by the Chief Wildlife Warden, Department of Environment, Forests and Climate Change, Government of Mizoram. MD thanks IBT Hub, Arya Vidyapeeth College, for help in the laboratory.

\section{Literature Cited}

Kumar, S., G. Stecher, and K. Tamura. 2016. MEGA7: Molecular Evolutionary Genetics Analysis Version 7.0 for Bigger Datasets. Molecular Biology and Evolution 33: 1870-1874.

Macey, J.R., A. Larson, N.B. Ananjeva, Z. Fang, and T.J. Papenfuss. 1997. Two novel gene orders and the role of light-strand replication in rearrangement of the vertebrate mitochondrial genome. Molecular Biology and Evolution 14: 91-104.

Purkayastha, J., M. Das, S.C. Bohra, A.M. Bauer, and I. Agarwal. 2020. Another new Cyrtodactylus (Squamata: Gekkonidae) from Guwahati, Assam, India. Zootaxa 4732: 375-392.

Uetz, P., P. Freed, and J. Hošek (eds.). 2019. The Reptile Database. <http://www. reptile-database.org>. 